\title{
Corrigendum
}

\section{How Lives Became Lists and Scientific Papers Became Data: Cataloguing Authorship during the Nineteenth Century - Corrigendum}

\begin{abstract}
ALEX CSISZAR
doi:10.1017/S0007087417000012, published by Cambridge University Press, 16 February 2017

On page 28 of the above article, the words "In September 1855 Henry travelled to Glasgow for the annual British Association meeting and described..." should read "In September 1855 Henry submitted a paper to be read at the British Association meeting in Glasgow in which he described..." to reflect that Henry did not attend the meeting in person.
\end{abstract}

\section{Reference}

Alex Csiszar, 'How Lives Became Lists and Scientific Papers Became Data: Cataloguing Authorship during the Nineteenth Century', BJHS (2017) 50(1), pp. 23-60. 